\title{
A Diagnostic Appraisal of Sorghum Farming in Striga Endemic Areas of Eritrea
}

\author{
Tadesse Yohannes ${ }^{1}$, Kahiu Ngugi ${ }^{1}$, Emmanuel Ariga ${ }^{1}$, Monday Ahonsi $^{2}$, Nasser $\mathrm{Yao}^{2} \&$ Tesfamichael Abraha ${ }^{3}$ \\ ${ }^{1}$ Department of Plant Sciences \& Crop Protection, University of Nairobi, Nairobi, Kenya \\ ${ }^{2}$ Biosciences Eastern and Central Africa, International Livestock Research Institute (BecA-ILRI) Hub, Nairobi, \\ Kenya \\ ${ }^{3}$ Hamelmalo Agricultural College (HAC), Keren, Eritrea \\ Correspondence: Tadesse Yohannes, Department of Plant Sciences \& Crop Protection, University of Nairobi, P.O. \\ Box 39063-00623, Nairobi, Kenya. Tel: 254-70-613-6350. E-.mail: tayohann@yahoo.com
}

\author{
Received: February 7, $2017 \quad$ Accepted: March 6, $2017 \quad$ Online Published: April 15, 2017 \\ doi:10.5539/jas.v9n5p133 URL: https://doi.org/10.5539/jas.v9n5p133
}

\begin{abstract}
Sorghum (Sorghum bicolour (L.) Moench), the most important cereal crop in Eritrea, is grown in more than 210,000 ha annually but its productivity is hampered by many factors including: farmer perception, lack of appropriate varieties, undeveloped seed systems, drought stress and Striga infestation. This study was aimed at understanding the sorghum smallholder livelihoods, farming systems, Striga incidence and infestation levels, and types of varieties grown in Striga infested sorghum growing areas. A semi structured questionnaire and focused group discussions were used to gather information from a total of 136 randomly selected farmers from three Striga endemic sub-regions of Eritrea namely, Hamelmalo, Goluj, and Tesseney. The results indicated that the most important cereal crops in the study area were sorghum, pear millet, ground nut and sesame. The most important constraint to sorghum production was identified as drought stress followed by Striga infestation. The majority of the respondents (81.6\%) reported that their sorghum was affected by Striga and the level of infestation varied from mild (10\%) to severe $(70 \%$ and above). Small-holder farmers also indicated that high grain yield, drought tolerance/resistance and Striga resistance were their most important criteria when selecting sorghum varieties. Up to 31 different landraces were listed as the most popular in the study area. The dominant source of seed for cultivation was the local varieties retained by farmers from previous harvests. The information documented from this study may be used in future as a basis for a participatory farmer-oriented sorghum breeding program.
\end{abstract}

Keywords: Eritrea, landraces, production constraint, sorghum, Striga

\section{Introduction}

Sorghum (Sorghum bicolor (L.) Moench) is Africa's second most important cereal after maize in terms of area harvested and annual production (FAOSTAT, 2014). In Eritrea, Sorghum is the most important cereal crop and it is commonly grown under rainfed conditions with very little or no capital inputs (Tesfamichael et al., 2013). Sorghum is also grown in spate irrigated areas of eastern lowland such as Sheeb and Wadilabka (Van Steenberger et al., 2010). Sorghum forms an important dietary component prepared as 'injera' (leavened bread) or as thick porridge and contains $68-74 \%$ carbohydrate, $8-15 \%$ protein, $2-5 \%$ fat, $8-16 \%$ water, $1-3 \%$ fiber and $1.5-2 \%$ ash (Perseglove, 1975). In this respect, sorghum meets most of the main diet requirements of the human body and its consumption is highest in the poorest and the most food-insecure regions of the world (Ejeta \& Knoll, 2007). However, the grain yield of sorghum is low due to not only biotic and abiotic stresses, but also to socio-economic factors such as farmer preference of what commodities to invest in a traditional farming system basically made of crops and livestock.

From 1998 to 2009, sorghum occupied an average of 210,197 ha of arable land in Eritrea and produced an average of $147,644.30$ metric tons of grain annually (MoA, 2010). This productivity is low $(0.63 \mathrm{t} / \mathrm{ha})$ compared to that in the east and central Africa (ECA) region (FAOSTAT, 2014), that has an average productivity of 0.93 $\mathrm{t} / \mathrm{ha}$ in the same period. Soil fertility, drought stress, pests and diseases were listed by Wortmann et al. (2006) as the major constraints and their relative importance varied between agro-zones. 
Increasing the productivity of sorghum in Eritrea will help improve household income, reduce poverty and food insecurity because the crop accounts for about $50 \%$ of total cereal production in Eritrea (MoA, 2010). Furthermore, because sorghum is well adapted to dry areas and gives reasonable yields in droughted seasons compared to other cereals in the region, farmers have used their land more productively in these agro-ecological zones where rainfall is scarce and unreliable.

Striga is one of the most severe constraints to cereal production in sub-Saharan Africa (Oswald \& Ransom, 2004). The increasing incidence of Striga has been attributed to poor soil fertility and structure, intensification of land-use through continuous cultivation and an expansion of cereal production (Rodenburg et al., 2005). In Eritrea, Striga mainly affects western part of the country where sorghum mono-cropping system is practiced. The African Agricultural Technology Foundation, AATF (2011) estimated that 64,000 ha of sorghum fields in Eritrea are affected by Striga. The extent to which Striga reduces the growth of its host is highly variable and depends on factors such as host plant genotype, parasite infestation level, and environment (van Ast et al., 2005).

The results of this study are likely to provide future insights into possible interventions needed to mitigate Striga infestation and the agronomic control measures that small-scale farmers would adopt in a cost effective manner.

\section{Method}

\subsection{Study Area Description}

A baseline survey was conducted in three sub-regions of Eritrea namely: Goluj, Tesseney and Hamelmalo where sorghum is the major crop and Striga hermonthica is the commonest threat to sorghum production. Agro-ecologically, Goluj $\left(140^{\circ} 74^{\prime} \mathrm{N}, 360^{\circ} 72^{\prime} \mathrm{E}\right)$ and Tesseney $\left(150^{\circ} 11^{\prime} \mathrm{N}, 360^{\circ} 66^{\prime} \mathrm{E}\right)$ sub-regions fall in the South Western Lowland Zone (SWLZ) of the country. The altitude of the agro-ecological zone ranges between 600 and 700 meters above sea level. The zone has hot-semiarid climate with an erratic rainfall that ranges between 300 and $700 \mathrm{~mm} /$ annum. According to NARI (2010), various soil types exist in the study area, but vertisols are the dominant ones. The sub-region Hamelmalo $\left(160^{\circ} 01^{\prime} \mathrm{N}, 380^{\circ} 20^{\prime} \mathrm{E}\right)$ is characterized by an altitude of 1280 meters above sea level with average annual rainfall of $479.2 \mathrm{~mm}$ and sandy and sandy loam soils.

\subsection{Data Collection and Analysis}

A semi structured questionnaire and focused group discussions were employed to gather information to determine the following major factors: production constraints, seed system; household structure, levels of Striga infestation; damage caused by Striga and presence/absence of tolerant/resistant varieties. A total of 136 farmers were randomly selected for the interview working in collaboration with the extension service of the Ministry of Agriculture and with village administrators of the three respective sub-regions.

The sampling technique used was sampling by proportion and the sample size was calculated as shown in Table 1 as described by Cochrane (1977). Sampling by proportion allows that sub-regions with many farmers growing sorghum under Striga infestation get higher sample size Table 1. Farmers for the interview were selected using simple random sampling by calculating the sampling interval for each sub-region as shown in Table 1 . Accordingly, the sampling interval was approximately 7 for all sub-regions; hence every $7^{\text {th }}$ farmer in a list of names arranged alphabetically was selected for the interview in each sub-region.

Focused group discussions were organized in each of the sub regions and comprised of farmers, extension workers, researchers and village administrators. Secondary data/information was reviewed to reinforce the study.

Table 1. Sample size and sampling interval determination for the surveyed area

\begin{tabular}{llll}
\hline Sub region & No of sorghum farmers $(A)$ & Sample size $(B)$ & Sampling Interval (A/B) \\
\hline Hamelmalo (H) & 309 & $(\mathrm{H} / \mathrm{D}) \times 136=(309 / 1001)^{*} 136=42$ & $309 / 42=7.3$ \\
Goluj (G) & 324 & $(\mathrm{G} / \mathrm{D}) \times 136=(324 / 1001)^{*} 136=44$ & $324 / 44=7.4$ \\
Teseney (T) & 368 & $(\mathrm{~T} / \mathrm{D}) \times 136=(300 / 1000)^{*} 136=50$ & $368 / 50=7.4$ \\
TOTAL (D) & 1001 & 136 & \\
\hline
\end{tabular}

Data collected from the diagnostic baseline survey were analyzed for means, descriptive statistics and tables, using the Statistical Product and Service Solutions (SPSS) software package. 


\section{Results and Discussion}

\subsection{Characteristics of Sampled Households}

There were similarities of responses among the farmers across the sub-regions in relation to age, sex and size of the households. The study revealed that almost all the sampled households were headed by men (Table 2). This could be explained by the fact that in Eritrea the basic ground-rules are that the husband is the head of the household. The average age of household head interviewed in the study area ranged between 53 to 55 years (Table 2).

Household size determines the availability of household labor supply and the results indicated large household size for all three sub-regions studied (Table 2). This may be attributed to the tendency of adult sons and daughters to remain in the parental households. Large household size tends to be allied with rural areas characterized by the advocacy or support of a high birth rate and extended family relations. The results corroborate a study by Biniam et al. (2014) conducted in different regions of Eritrea and that reported family size to be in the range of 5.4 to 7.8 .

Table 2. Characteristics of sampled households

\begin{tabular}{llll}
\hline Characteristics & Hamelmalo & Tesseney & Goluj \\
\hline Male household head (\%) & 100 & 90 & 97.6 \\
Average age of household head (years) & 53.7 & 54.4 & 55 \\
Average household size (number) & 7.2 & 5.7 & 8 \\
\hline
\end{tabular}

Land is the major natural capital for smallholder farmers. All the households interviewed indicated to have owned their farm fields (Table 3). In Eritrea, land belongs to the government and each household in the farming community is entitled to have land based on their family size. Reports from Ministry of Agriculture (MoA) and local government of zone Gashbarka offices indicated that there are two types of tenure systems; where every farming household is entitled to own about two hectares of land for subsistence agriculture but the rest of the cultivable farmland is reserved for commercial rain-fed agriculture (NARI, 2010). The average area of land available for farming was different in each sub-region as shown in Table 3. The average available land (farmer owned land) was by far larger in Goluj (5.4 ha) compared to Hamelmalo (1.5 ha) and Tesseney (2.6 ha) sub-regions. The relatively larger size of owned farmland in Goluj sub-region may be due to the existence of many commercial rain-fed farming in this sub-region. The other farm fields were either rented from farmers or share cultivated with other farmers as indicated in Table 3.

Table 3. Average farm land size in sub-regions of Hamelmalo, Goluj and Tesseney

\begin{tabular}{|c|c|c|c|c|c|c|}
\hline \multirow{2}{*}{ Land tenure } & \multicolumn{2}{|c|}{ Hamelmalo } & \multicolumn{2}{|c|}{ Goluj } & \multicolumn{2}{|c|}{ Tesseney } \\
\hline & $\mathrm{N}$ & ha & $\mathrm{N}$ & ha & $\mathrm{N}$ & ha \\
\hline Owned land & 44 & 1.5 & 42 & 5.4 & 50 & 2.6 \\
\hline Rented & 23 & 1.6 & 7 & 3.7 & 9 & 2 \\
\hline Shared & 13 & 1.7 & 5 & 7.4 & 0 & 0 \\
\hline
\end{tabular}

Note. $\mathrm{N}=$ number of respondents.

Almost all the farmers practiced both crop and livestock production as major sources of food, feed, and income. Most farmers had a mix of livestock which included oxen, cattle, sheep, goats, donkeys and chicken. The main crops grown included: sorghum, pearl millet, sesame, ground nut and maize as shown in Table 4. Sorghum was listed as the most important crop in Tesseney and Goluj sub-regions where as in Hamelmalo, Pearl millet was the most preferred crop followed by sorghum. 
Table 4. Frequency of respondents to the level of importance of the crop in question

\begin{tabular}{|c|c|c|c|c|c|c|c|c|c|c|c|c|c|c|c|}
\hline \multirow{3}{*}{ Crop type } & \multicolumn{15}{|c|}{ Frequency of respondents } \\
\hline & \multicolumn{5}{|c|}{ Hamelmalo } & \multicolumn{5}{|c|}{ Tesseney } & \multicolumn{5}{|c|}{ Goluj } \\
\hline & EI & VI & MI & SI & LI & EI & VI & MI & SI & LI & EI & VI & MI & SI & $\overline{\text { LI }}$ \\
\hline Sorghum & 1 & 32 & 11 & 0 & 0 & 46 & 4 & 0 & 0 & 0 & 30 & 12 & 0 & 0 & 0 \\
\hline Maize & 0 & 0 & 1 & 12 & 31 & 0 & 1 & 2 & 21 & 26 & 0 & 0 & 3 & 15 & 24 \\
\hline P.millet & 38 & 5 & 1 & 0 & 0 & 0 & 8 & 36 & 6 & 0 & 0 & 2 & 36 & 4 & 0 \\
\hline Ground nut & 5 & 7 & 32 & 0 & 0 & 0 & 0 & 0 & 20 & 30 & 0 & 0 & 1 & 25 & 16 \\
\hline Sesame & 0 & 1 & 1 & 0 & 42 & 4 & 32 & 13 & 0 & 1 & 12 & 27 & 3 & 0 & 0 \\
\hline
\end{tabular}

Note. $\mathrm{EI}=$ extremely important, $\mathrm{VI}=$ very important, $\mathrm{MI}=$ moderately important, $\mathrm{SI}=$ slightly important, $\mathrm{IL}=$ less important.

In selecting a variety, farmers considered different characteristics of the crop in question as shown in Table 5 . Accordingly, high yield, drought and Striga resistance were reported as the most important characteristics of a good sorghum variety (Table 5). Such desirable traits of a crop were crucial in the selection and adoption of a variety. Other characters considered as important by the farmers were, adaptation to the local environment, plant height (medium to tall varieties more preferred), grain size and grain color as indicated in Table 5. Tesfamichael et al. (2013) reported similar findings that showed that adaptability and grain yield are among the most important characteristics of a good sorghum seed in the sampled agro-ecological zones.

Table 5. Frequency of respondents on characteristics of an ideal sorghum variety across the sub zones

\begin{tabular}{|c|c|c|c|c|c|c|c|c|c|}
\hline \multirow{2}{*}{ Trait/characteristic } & \multicolumn{3}{|c|}{ Hamelmalo } & \multicolumn{3}{|c|}{ Tesseney } & \multicolumn{3}{|c|}{ Goluj } \\
\hline & MI & SWI & LI & MI & SWI & $\mathbf{L I}$ & MI & SWI & LI \\
\hline High yield & 39 & 4 & 1 & 37 & 11 & 2 & 33 & 7 & 2 \\
\hline Adaptation & 1 & 25 & 18 & 9 & 40 & 1 & 7 & 35 & 0 \\
\hline Striga resistance & 15 & 28 & 1 & 25 & 21 & 4 & 25 & 17 & 0 \\
\hline Drought resistance & 15 & 27 & 2 & 25 & 24 & 1 & 23 & 17 & 2 \\
\hline Plant height & 4 & 16 & 24 & 5 & 26 & 19 & 1 & 18 & 23 \\
\hline Panicle size & 14 & 24 & 6 & 22 & 19 & 9 & 10 & 27 & 5 \\
\hline Grain size & 5 & 18 & 21 & 7 & 30 & 13 & 0 & 26 & 16 \\
\hline Grain color & 0 & 11 & 33 & 1 & 17 & 32 & 0 & 10 & 32 \\
\hline Suitability food preparation & 4 & 25 & 15 & 6 & 26 & 18 & 6 & 21 & 15 \\
\hline Tillering & 1 & 15 & 28 & 2 & 16 & 32 & 0 & 1 & 41 \\
\hline
\end{tabular}

Note. $\mathrm{MI}=$ most important, $\mathrm{SWI}=$ somewhat important, $\mathrm{LI}=$ least important.

The dominant sorghum seed source (65.4\%) for cultivation in the study area was from the seeds of local varieties (landraces) retained by farmers themselves from previous harvests (Figure 1). A few (4.2\%) of the interviewed farmers had acquired improved varieties from Ministry of Agriculture offices, research centers or local markets. Our study confirmed that farmers have a deep rooted custom of conserving their own varieties (landraces) for subsequent uses and consequently for passing them from generation to generation. 


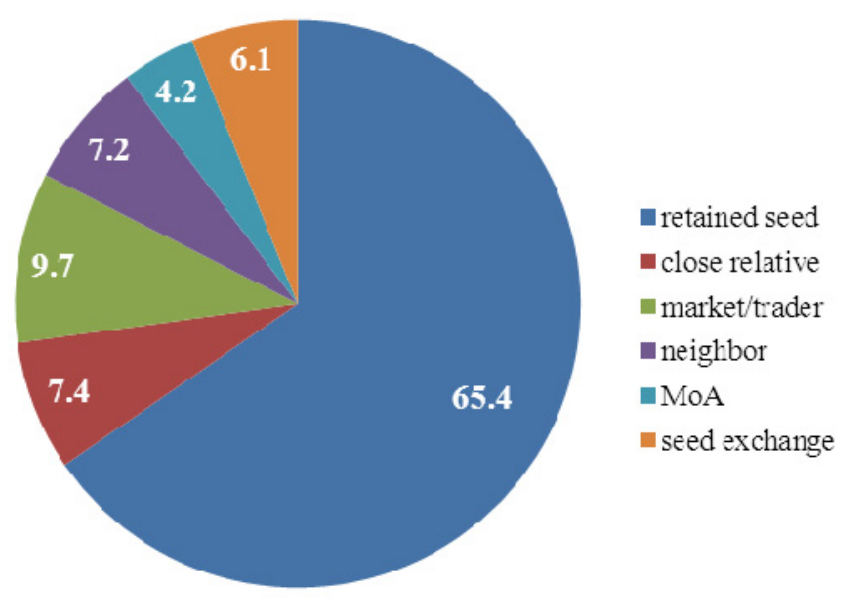

Figure 1. Sorghum seed sources of the households in percentage

\subsection{Fertilizer Use}

The common means of enhancing soil fertility in small farm agriculture has been to use chemical fertilizers to increase food production (Mignouna et al., 2013). Despite this fact however, results of this study revealed that majority of the respondents (79.4\%) do not apply fertilizer to their sorghum farm (Table 6). This could be one of the reasons why sorghum productivity is low in the study area. This finding is similar to an earlier report by Tesfamichael et al. (2013) which indicated that commercial fertilizer is rarely used by farmers in the Goluj and Tesseney sub-regions. In the Hamelmalo sub-region some farmers applied farm yard manure in their fields located near the homestead. Despite not using fertilizers, the farmers interviewed believed that the use of fertilizer for sorghum production is important. However, unaffordable costs, unavailability of fertilizer and the moisture stress at the end of growing season precluded the farmers from the use of commercial fertilizers.

Table 6. Respondents' frequency on use of fertilizer

\begin{tabular}{|c|c|c|c|c|c|c|}
\hline \multirow{2}{*}{ Sub zone } & \multicolumn{2}{|c|}{ Application of fertilizer } & \multicolumn{2}{|c|}{ Availability of fertilizer on time } & \multicolumn{2}{|c|}{ Right amount of fertilizer } \\
\hline & Yes & No & Yes & No & Yes & No \\
\hline Hamelmalo & 20 & 24 & 30 & 14 & 21 & 23 \\
\hline Tesseney & 6 & 44 & 14 & 36 & 12 & 38 \\
\hline Goluj & 2 & 40 & 9 & 33 & 6 & 36 \\
\hline Total & 28 & 108 & 53 & 83 & 39 & 97 \\
\hline$\%$ & 20.6 & 79.4 & 39 & 61 & 28.7 & 71.3 \\
\hline
\end{tabular}

\subsection{Sorghum Production Constraints}

Over $80 \%$ in the surveyed area reported drought stress as the most important constraint to sorghum production which was followed by Striga as indicated in Table 7 as also reported by Tesfamichael et al. (2013). Other minor constraints to sorghum production included access to crop protection facilities, fertilizer, and labor as shown in Table 7. 
Table 7. Frequency of sorghum production constraints in sub-regions Hamelmalo, Teseney and Goluj

\begin{tabular}{|c|c|c|c|c|c|c|c|c|c|}
\hline \multirow{2}{*}{ Constraints } & \multicolumn{3}{|c|}{ Hamelmalo } & \multicolumn{3}{|c|}{ Tesseney } & \multicolumn{3}{|c|}{ Goluj } \\
\hline & MI & SWI & LI & MI & SWI & LI & MI & SWI & LI \\
\hline Drought & 22 & 17 & 5 & 35 & 5 & 10 & 21 & 14 & 7 \\
\hline Striga infestation & 17 & 20 & 7 & 29 & 10 & 11 & 34 & 4 & 4 \\
\hline Quality seed & 0 & 0 & 42 & 0 & 4 & 46 & 0 & 0 & 42 \\
\hline Access to labor & 0 & 1 & 43 & 4 & 7 & 38 & 4 & 6 & 32 \\
\hline Access to credit & 0 & 0 & 44 & 2 & 4 & 44 & 4 & 9 & 29 \\
\hline Access to land & 1 & 1 & 42 & 1 & 1 & 48 & 0 & 2 & 40 \\
\hline Access to irrigation & 0 & 1 & 42 & 0 & 0 & 50 & 0 & 0 & 42 \\
\hline Access to crop protection & 8 & 16 & 20 & 3 & 10 & 36 & 1 & 4 & 37 \\
\hline Fertilizer & 3 & 10 & 31 & 0 & 0 & 52 & 0 & 0 & 42 \\
\hline Market & 0 & 0 & 44 & 2 & 2 & 46 & 1 & 0 & 41 \\
\hline
\end{tabular}

\subsection{Perception of Farmers to Striga Incidence and Extent in Sorghum Production}

Farmers considered Striga hand weeding at its early stage as the most effective practice to reduce its impact in subsequent cropping seasons. This practice helped in reducing the multiplication of Striga. In the past researchers indicated that even though hand weeding prevents further seed multiplication of Striga weed, it is a less efficient control method once the Striga is established (Woomer et al., 2004). Furthermore, hand weeding of Striga may not increase the yield of already infected plant because most of the damage $(75 \%)$ occurs before the weed emerges above the ground (Ejeta, 2007).

The majority of the respondents $(81.6 \%)$ in the study area reported that their sorghum farm was infested with Striga (Table 8). The level of infestation varied from mild to severe (Table 8 ). Almost $49 \%$ of the respondents reported that the proportion of their sorghum farm infested with Striga exceeded $70 \%$. This may infer that the existing varieties were less resistant to Striga and hence need farther improvement for resistance. The intensity of Striga infestation was exacerbated by drought stress. A field survey on Striga by National Agricultural Research Institute (NARI) of Eritrea also showed that the mean number of Striga plants per meter square in the study area ranged 71-335 (NARI, 2001). Considering that Striga produces 10,000-100,000 seeds/plant (Parker \& Riches, 1993), the level of soil infestation could exponentially increase every season and leads to a devastating effect on the sorghum farmers. Reports in the neighboring countries such as Ethiopia (Gebretsadik et al., 2014), Sudan (Gemar \& Mohamed, 2013), Kenya (Kanampiu et al., 2002) and Uganda (Olupot et al., 2005) have indicated that the incidence and extent of Striga infestation is increasing as sorghum hectarage rises and therefore there is need for regional approach to mitigate the challenge.

Table 8. Frequency of farmers' response on if their sorghum farm was infested with Striga and the proportion of infestation

\begin{tabular}{|c|c|c|c|c|c|c|}
\hline \multirow{2}{*}{ Sub-zone } & \multicolumn{2}{|c|}{ Response } & \multicolumn{4}{|c|}{ Proportion and number of respondents } \\
\hline & Yes & No & $<10 \%$ & $11-40 \%$ & $41-70 \%$ & $>70 \%$ \\
\hline Hamelmalo & 36 & 8 & 0 & 5 & 20 & 19 \\
\hline Tesesney & 42 & 8 & 7 & 13 & 10 & 20 \\
\hline Goluj & 33 & 9 & 0 & 3 & 11 & 28 \\
\hline Total & 111 & 25 & 7 & 21 & 41 & 67 \\
\hline$\%$ & 81.6 & 18.4 & 5.1 & 15.4 & 30.1 & 49.3 \\
\hline
\end{tabular}

\subsection{Commonly Grown Sorghum Varieties and Their Preferred Traits}

A wide variety of sorghum landraces which have been grown in the study area were mentioned by farmers (Table 9). Some of the landraces were commonly recognized by most farmers across the three sub-regions studied, while some were common only in one or two of the sub-regions. A large number of landraces show the existence of diverse genetic resources of sorghum which have evolved under different environmental conditions and management practices by smallholder farmers. Genetic diversity study on sorghum landraces from Eritrea by Ghebru et al. (2002) and Tesfamichael et al. (2014) using molecular markers reported a range of genetic diversity 
which supports the availability of a diverse of landraces mentioned by the interviewed farmers. Such diversity could be exploited in sorghum breeding programs for further improvement.

Only a small number of improved sorghum varieties were mentioned by farmers across the three sub-regions (Table 9). It was noted that farmers' preference to a particular variety was associated with certain characteristic such as drought resistance, early maturity, resistance to Striga, market value, and cooking quality.

Table 9. List of sorghum varieties commonly grown in the study sub-zones and their associated characteristics as described by farmers

\begin{tabular}{lll}
\hline Sub-zone & Variety name & Suggested traits \\
\hline Hamelmalo & Bariyay (Red), Shigrey, Meriro, Senadir, Red-sorghum, white sorghum, Abu-arbin & Early maturity \\
& Bariyay (white), Helle, Wediaker, Embulbul, Kibra, Hariray, Hamelmalo & Striga resistance \\
Goluj & Red-Bariyay, Bazenay, Arfaegedem, Keyih,Bazenay, Feteret, Karakora, Baryai, Ghedem hamam & Early maturity \\
& Bariyay, Wedi-Aker, Hariray, wedi-Fereg & Striga resistance \\
& Bazenay, Bariyay & Drought resistance \\
Tesseney & Hugurtay, Bariyay, Hariray & High yield \\
& FP290 (shambuko), ICSV210 (Bshuka), ICSV111 (Seare) & \\
& Ghedem hamam, Aklomay, Nugud, Esferf, Semsem & Early maturity \\
& Hariray, Wediaker, Bariyay Embulbul, Wediferej, Wedi-arbaa & Striga resistance \\
& Bazenay, Bariyay & Drought resistance
\end{tabular}

Note. Bold scripts are improved varieties.

\section{Conclusion}

This study identified farmers' sorghum production opportunities, the main constraints, the use of indigenous knowledge in farming, farmers' perceptions and preferences of biological traits in varieties currently grown in Hamelmalo, Goluj and Tesseney sub-regions. Drought stress and Striga infestation were identified as the most important constraints limiting sorghum production. Farmers in the study area preferred high yield, drought resistance and Striga resistance traits as the most important for sorghum varietal selection criteria. But the relative importance of constraints varied considerably within and between the three endemic Striga sub-regions studied. The farmers interviewed here indicated that landraces have wide adaptation to the farming systems, with relatively better level of drought tolerance. The study also identified that Striga infestation is high in all the three sub-regions studied, but more so in the Goluj sub-region. This implies that there is need to deploy efficient strategies to limit the rapid increase in soil Striga seed density and spread of Striga to new farming lands in Eritrea. Thus, based on farmers' perceptions, sorghum improvement programs in Eritrea should focus on developing cultivars that incorporate farmers-preferred traits with emphasis on Striga and drought resistance.

\section{Acknowledgements}

The authors are grateful to farmers of the study area who made this study possible by actively participating. We are also grateful for the kind assistance of the Ministry of Agriculture and village administration office staffs and research centers in the study area.

\section{References}

African Agricultural Technology Foundation (AATF). (2011). Feasibility study on Striga control in sorghum (pp. 11-20). The African Agricultural Technology Foundation, Nairobi, Kenya.

Biniam, M. G., Githiri, S. M., Tadesse, M., \& Kasili, R. W. (2014). Diagnostic survey on potato production practices in Eritrea. ARPN Journal of Agricultural and Biological Science, 9(12), 444-453. 
Cochran, W. G. (1977). Sampling Techniques (pp. 74-76). John Wiley \& Sons, New York.

Ejeta, G. (2007). Breeding for Striga resistance in sorghum: Exploitation of an intricate host-parasite biology. Crop Science, 47, 216-227. https://doi.org/10.2135/cropsci2007.04.0011IPBS

Ejeta, G., \& Knoll, J. (2007). Marker-assisted selection in sorghum. In R. K. Varshney \& R. Tuberosa (Eds.), Genomics Application in Crops (Vol. 2, pp. 187-205). https://doi.org/10.1007/978-1-4020-6297-1_9

FAOSTAT. (2014). Retrieved from http://faostat3.fao.org/faostat-gateway/go/to/download/Q/*/E

Gamar, Y. A., \& Mohamed, A. H. (2013). Introgression of Striga Resistance Genes into a Sudanese Sorghum Cultivar, Tabat, Using Marker Assisted Selection (MAS). Greener Journal of Agricultural Sciences, 3(7), 550-556. https://doi.org/10.15580/GJAS.2013.3.061013654

Gebretsadik, R., Shimelis, H., Laing, M. D., Tongoona, P., \& Mandefro, N. (2014). A diagnostic appraisal of the sorghum farming system and breeding priorities in Striga infested agro-ecologies of Ethiopia. Agricultural Systems, 123, 54-61. https://doi.org/10.1016/j.agsy.2013.08.008

Ghebru, B., Schmidt, R. J., \& Bennetzen, J. L. (2002). Genetic diversity of Eritrea sorghum landraces assessed with simple sequence repeats (SSR) markers. Theoretical and Applied Genetics, 105, $229-236$. https://doi.org/10.1007/s00122-002-0929-x

Kanampiu, F., Friesen, D., \& Gressel, J. (2002). CIMMYT unveils herbicide-coated maize seed technology for Striga control. Haustorium, 42, 1-3.

Mignouna, B. D., Abdoulaye, T., Kamara, A., \& Oluoch, M. (2013). Baseline study of smallholder farmers in Striga-infested maize and cowpea-growing areas of northern Nigeria (p. 60). International Institute of Tropical Agriculture, Ibadan, Nigeria.

Ministry of Agriculture (MoA). (2010). Annual crop production report, planning and statistics office of MoA. Asmara, Eritrea.

National Agricultural Research Institute of Eritrea (NARI). (2010). SWOT analysis report on the existing sorghum market chains in Zoba Gash-barka Asmara. Eritrea.

National Agricultural Research Institute of Eritrea (NARI). (2010). Annual report Asmara. Eritrea.

Olupot, J. R., Abaijuka, I., Dradiku, F., Edema, P., \& Mukalazi, J. (2005). Striga infestation in the West Nile Agro-Ecological Zone of Uganda: The Socio-economic perspective and the way forward. African Crop Science Society, 7, 1507-1511.

Oswald, A., \& Ransom, J. K. (2004). Response of maize varieties to Striga infestation. Crop Protection, 23, 89-94. https://doi.org/10.1016/S0261-2194(03)00173-X

Parker, C., \& Riches, C. R. (1993). Parasitic weeds of the world: Biology and control. Cab International, Wallingford.

Perseglove, J. R. (Ed.). (1975). Tropical crops: Monocotyledons (Vols. 1 \& 2). Longman Group Ltd.

Rodenburg, J., Bastiaans, L., Weltzien, E., \& Hess, D. E. (2005). How can selection for Striga resistance and tolerance based on field observations be improved? Field Crops Research, 93, 34-50. http://dx.doi.org/ 10.1016/j.fcr.2004.09.004

Tesfamichael, A., B., Githiri, S. M., Kasili, R. W., Skilton, R. A., Solomon, M., \& Nyende, A. (2014). Genetic Diversity Analysis of Eritrean Sorghum (Sorghum bicolor (L.) Moench) Germplasm using SSR Markers. Molecular Plant Breeding, 5(13), 1-12. http://dx.doi.org/10.5376/mpb.2014.05.0013

Tesfamichael, A., Nyende, A. B., Githiri, S. M., Kasili, R. W., \& Woldeamlak, A. (2013). Documentation of sorghum (Sorghum bicolor L. Moench) landraces: Production, utilization and challenges in Eritrea. ARPN Journal of Agricultural and Biological Science, 8(6), 498-508.

Van Ast, A., Katileb, S., \& Bastiaansa, L. (2005). Cultural control measures to diminish sorghum yield loss and parasite success under Striga hermonthica infestation. Crop Protection, 24(12), 1023-1034. https://doi.org/10.1016/j.cropro.2005.02.008

Van Steenbergen, F., Lawrence, P., Mehari, A., Salman, M., \& Faurès, J. M. (2010). Guidelines on spate irrigation (p. 233). FAO, Rome.

Woomer, P. L., Mukhwana, E. J., Odhiambo, G., Okello, D., Omare, M., \& Sanginga, N. (2004). Striga control in western Kenya: Raising awareness, containing and reducing the infestation and developing strategies for 
eradication. A Report on Collaborative Project Involving the African Agricultural Technology Foundation (AATF) and the Western Regional Alliance for Technolgy Evaluation, Kenya.

Wortmann, C. S., Mamo, M., Abebe, G., Mburu, C., Kayuki, K. C., Letayo, E., \& Xerinda, S. (2006). The Atlas of Sorghum Production in Five Countries of Eastern Africa. University of Nebraska, Lincoln, USA.

\section{Copyrights}

Copyright for this article is retained by the author(s), with first publication rights granted to the journal.

This is an open-access article distributed under the terms and conditions of the Creative Commons Attribution license (http://creativecommons.org/licenses/by/4.0/). 